\title{
ALKALINE PHOSPHATASE ACTIVITY OF THE SERUM IN KWASHIORKOR
}

\author{
BY \\ RUTH SCHWARTZ \\ From the Medical Research Council Group for Research in Infantile Malnutrition, Mulago Hospital, \\ Kampala, Uganda
}

(RECEIVED FOR PUBLICATION SEPTEMBER 9, 1955)

There are few reports of alkaline phosphatase activity in the serum of children suffering from kwashiorkor. The values quoted are somewhat conflicting: Waterlow (1948) found an average level of 19.7 King-Armstrong units in eight cases of "fatty liver disease" in Jamaica, and Jayasekera, de Mel, and Cullumbine (1951) reported an average value of 15.8 units in 40 children with kwashiorkor investigated in Ceylon. Both values fall within the normal range of 15 to $20 \mathrm{King}$ Armstrong units quoted by Behrendt (1949). In Kampala the average of 23 estimations in children newly admitted for treatment of acute kwashiorkor was 11.8 units with a range of 4.7 to 23.1 units (Dean and Schwartz, 1953). Workers in Capetown, Johannesburg, and Gautemala City have also found low values (Hansen, Bersohn, and Behar, personal communications).

Low activities have been reported for most of the blood and tissue enzymes investigated in kwashiorkor. In the Kampala investigation already mentioned the activity of three serum enzymes (amylase, non-specific esterase, and pseudocholinesterase) was low when the children were admitted, and rose after two to three weeks of treatment to levels approaching, and often exceeding, those that were considered normal for healthy children. Enzymes in duodenal juice (amylase, lipase, and trypsin) showed similar alterations. The pattern for alkaline phosphatase was different : in about half the children investigated the levels fell so that by the eighth day the average value was 9.5 units. Subsequently there was a steady rise in activity up to the time when the children were discharged, usually about 30 days after admission. Bersohn (personal communication) also frequently found a fall in alkaline phosphatase activity in Johannesburg children. As at Kampala, the fall did not occur in all cases, but it was frequent enough to merit attention.
Liver biopsy tissue taken from Indian children who had kwashiorkor was examined by histochemical methods by Sriramachari and Ramalingaswami (1953) and by Ramalingaswami, Sriramachari, and Patwardhan (1954) and was found to show an increased concentration of alkaline phosphatase. It was pointed out that this finding was difficult to reconcile with the low values reported in Kampala for the serum enzyme.

Several workers have observed increased concentrations of alkaline phosphatase in the livers of adult rats fed on diets deficient in protein (Miller, 1950; Ely and Ross, 1951; Rosenthal, Fahl and Vars, 1952). Rosenthal et al. found that the increased activity in liver tissue was accompanied by a change in its response to magnesium activation and cyanide inhibition. In normaliy fed rats the liver phosphatase was strongly activated by $\mathrm{Mg}^{++}$and only slightly inhibited by $\mathrm{CN}^{-}$. In the plasma, inhibition by $\mathrm{CN}^{-}$was almost complete, but the degree of activation by $\mathrm{Mg}^{++}$was considerably less than in the liver tissue. Fasting lowered the total level of enzyme in plasma and in the liver, but there was no change in the response of the liver enzyme to $\mathrm{Mg}^{++}$and $\mathrm{CN}^{-}$. After the rats had been given a proteinfree diet for two weeks the concentration of alkaline phosphatase in the liver was increased, the response to $\mathrm{Mg}^{++}$was less and the response to $\mathrm{CN}^{-}$greater than in normal rats. The enzyme in plasma was apparently equally affected by fasting and protein depletion: the level was lowered to about half the normal value. The figures given suggest that the response to $\mathrm{Mg}^{++}$was slightly greater than normal and the sensitivity to $\mathrm{CN}^{-}$ somewhat less, but the authors presumably did not think these variations significant as they did not comment on them. They suggested that the changes in the liver tissue might be explained by 
postulating that the liver normally disposed of extrahepatic alkaline phosphatase, and that this function was impaired by protein depletion.

The aetiology of kwashiorkor is not yet fully understood, but it is generally agreed that a deficiency of protein in the diet is an important factor. It was thought, therefore, that some changes which have been found in proteindepleted rats might also occur in acute kwashiorkor. Much work has been done on serum alkaline phosphatase in pathological and normal conditions in man, but little is known of its origins. Bodansky and Jaffe (1933-34), from a consideration of high values found in jaundice, suggested that part of the serum alkaline phosphatase might be produced in the liver. Previously the enzyme was thought to originate in bone. Roche and Sarles $(1950,1951)$ determined the affinity constants of alkaline phosphatases found in different organs, and came to the conclusion that the enzyme of human plasma resembled that of liver ; they found no difference in the nature of the alkaline phosphatase in plasma from normal adults and from patients suffering from various abnormal conditions of liver or bone.

The fall in phosphatase activity found in children at the beginning of treatment has not been reported in the blood of rats repleted after protein depletion, and there is evidence that the blood enzyme of rats is different in origin and general properties from that of humans. It seemed possible, however, that an investigation on the lines followed by Rosenthal et al. (1952) might explain the fall. In the children serum, and not plasma, was used, and for various reasons liver tissue could not be analysed.

\section{Material and Methods}

The Children.-Three groups of children were investigated, all between the ages of 6 months and 3 years.

Group (1): Children without Signs of Kwashiorkor. -All the 13 children in this group had been brought to the Out-patient Department of Mulago Hospital for the treatment of upper respiratory infections or mild malaria. There are no " normal " values for Uganda children, and uncertainties regarding ages and other reasons make the collection of "normal " data difficult (Dean, 1954). The selection was therefore to some extent empirical, but none of the children in this group showed any detectable degree of growth failure, or signs of kwashiorkor or of any other severe illness.

Group (2): Children with Slight Kwashiorkor.This group, which numbered 15 , consisted chiefly of children who had been brought to Mulago Hospital as out-patients to be treated for various mild infective conditions, and were found to have in addition some of the slighter signs of kwashiorkor. Some of them were admitted to the ward of the infantile malnutrition group for treatment. All the children had a marked degree of growth failure and their hair was discoloured and of altered texture. Dry and lustreless skin was common in this group, and slight oedema was sometimes present, but children with definite dermatosis or other symptoms of severe kwashiorkor were not included.

Group (3): Children with Severe Kwashiorkor.The 22 children in this group were admitted to the ward of the infantile malnutrition group with the diagnosis of kwashiorkor. The signs of the disease as they are usually seen in Kampala have been described in full elsewhere (Trowell, Davies, and Dean, 1954). They include growth failure, changes in the hair and skin, oedema, digestive failure, anorexia, and characteristic psychological changes. Severity is not easy to define because it is rare for a child to show simultaneously all the signs of the advanced disease ; frequently the condition cannot be judged with accuracy until the rate of response to treatment has been observed. Oedema with marked dermatosis always indicates severity, especially if there is much anorexia, but often the child who is thought to be acutely ill at the beginning will make a rapid recovery. In the severest cases there is usually considerable wasting, although this may become apparent only when the oedema is lost after some days of treatment. Because growth failure, wasting, and oedema usually occur together, it is not possible to correlate the degree of underweight for age with severity. The only objective measurement of severity that could be used in the present series with any degree of confidence was the level of the serum albumin: if it was under $1.8 \mathrm{~g} . / 100 \mathrm{ml}$. the case was regarded as severe. In such cases the total serum protein was usually from 3.5 to $4.5 \mathrm{~g} . / 100 \mathrm{ml}$.

All the children in this group were treated with diets based on milk protein (Dean, 1952). They were bled from the superior sagittal sinus or the external jugular vein on admission and, as far as possible, every seven days afterwards. The blood was allowed to clot, was ringed, and centrifuged without delay, and the serum was stored at $-5^{\circ} \mathrm{C}$.

The blood from the children in the other groups was taken and treated in exactly the same way, but only one sample was obtained from each child, either in the Out-patient Department or in the hospital wards.

Chemical Methods. - The method employed for the measurement of enzyme activity was that described by Rosenthal and others (1952), but certain modifications were made because the activity of the alkaline phosphatase is much lower in human serum than it is in rat serum and because it was necessary to use the minimum amount of serum.

In four microcentrifuge tubes $(0.8 \mathrm{~cm} . \times 7.5 \mathrm{~cm}$.) were placed $0.10 \mathrm{ml}$. of $0.1 M$ sodium- $\beta$-glycerophosphate (containing less than $0.1 \% \quad \alpha$-glycero- 
phosphate), and $0.10 \mathrm{ml}$. of 2-amino-2-methyl-1, 3propanediol buffer, $p \mathrm{H}=9.6$ (Gomori, 1946). Additions ivere made as follows:

Tube $1,0.10 \mathrm{ml}$. of distilled water and $0.05 \mathrm{ml}$. of $0.06 M$ magnesium chloride.

Tube $2,0.10 \mathrm{ml}$. of distilled water and $0.05 \mathrm{ml}$. of $0.08 M$ potassium cyanide which had been adjusted to $p \mathrm{H} 9.6$ with $N \mathrm{HCl}$.

Tubes 3 and $4,0.15 \mathrm{ml}$. of distilled water.

Tubes 1, 2, and 3 were incubated with $0.05 \mathrm{ml}$. of undiluted serum for three hours at $37^{\circ} \mathrm{C}$. The reaction was then stopped by adding $0.10 \mathrm{ml}$. of $25 \%$ trichloracetic acid.

Tube 4 was a blank to which $0.10 \mathrm{ml}$. of trichloracetic acid was added before $0.05 \mathrm{ml}$. serum.

The tubes were centrifuged for five minutes at about 8,000 r.p.m., then $0.40 \mathrm{ml}$. of the supernatant was taken off with a Carlsberg constriction pipette and added to $2.4 \mathrm{ml}$. of distilled water. The phosphate was estimated by the method of Allen (1940), but the final volume was reduced to $4.0 \mathrm{ml}$. : the colour was developed by the addition of $0.5 \mathrm{ml}$. of $60 \%$ perchloric acid, $0.2 \mathrm{ml}$. of $8.3 \%$ ammonium molybdate, and $0.5 \mathrm{ml}$. of Allen's amidol reagent $(2.0 \mathrm{~g}$. amidol and $40.0 \mathrm{~g}$. sodium metabisulphite made up to $200 \mathrm{ml}$.). A blank and standards containing $5 \mu \mathrm{g}$. and $10 \mu \mathrm{g}$. $\mathbf{P}$ were included. The standards were prepared from potassium dihydrogen phosphate. The colour was read in an E.E.L. photo-electric colorimeter using an Ilford filter No. 608. A very good linear relationship of colour to concentration was obtained from 1 to $20 \mathrm{mg}$. P. The calculation used was as follows:

Mg. $P$ released by $100 \mathrm{ml}$. serum =

$$
\begin{aligned}
& \frac{\text { Reading of test }}{\text { Reading of }} \frac{100}{10 \mathrm{~g} . \text { standard }} \times \frac{105}{0.05} \times \frac{5}{1000} \\
& =\frac{\text { Reading of test }}{\text { Reading of standard }} \times 25
\end{aligned}
$$

To conform with convention an arbitrary unit has been adopted: it is the amount of enzyme that liberated $1 \mathrm{mg}$. $P$ under the conditions described. The calculation therefore gives the answer in units. The unit is approximately three times as great as the Bodansky unit, but the comparison is not exact because the conditions of hydrolysis in Bodansky's method are somewhat different from those employed in this investigation. It should be slightly greater than the King-Armstrong unit, which is two and a half times the Bodansky unit.

Extending the reaction time from the one hour used by Rosenthal et al. (1952) to three hours was not considered ideal, but it was necessary to measure low activities, and the modified method was not suitable for the estimation of the small amounts of phosphate released in one hour. The activities of some sera were measured at one hour and three hours; they showed no falling off of activity during the longer incubation time.

For the phosphatase estimations done earlier in Kampala (Dean and Schwartz, 1953) the KingArmstrong method was used which measured activity in serum without activation by added $\mathrm{Mg}^{++}$. In the present series the activity so found is referred to as "basic." Under the conditions of the experiments $\mathrm{Mg}++$ caused an increase in activity and $\mathrm{CN}^{-}$a reduction. The increase in value due to activation, and the residual value found after inhibition, have been expressed as percentages of the basic value.

\section{Results}

Table I shows the basic values of serum alkaline phosphatase, and the effects of magnesium activation and cyanide inhibition.

Basic Activity of Alkaline Phosphatase.-The average value for the group of children in good general condition was 30.8 units. The values

TABLE I

ALKALINE PHOSPHATASE ACTIVITY AND RESPONSE TO MG M $^{++}$AND CN OF THE SERUM OF CHILDREN WITHOUT SIGNS OF KWASHIORKOR, CHILDREN WITH SLIGHT KWASHIORKOR, AND CHILDREN WITH ACUTE KWASHIORKOR ON ADMISSION TO HOSPITAL AND DURING RECOVERY

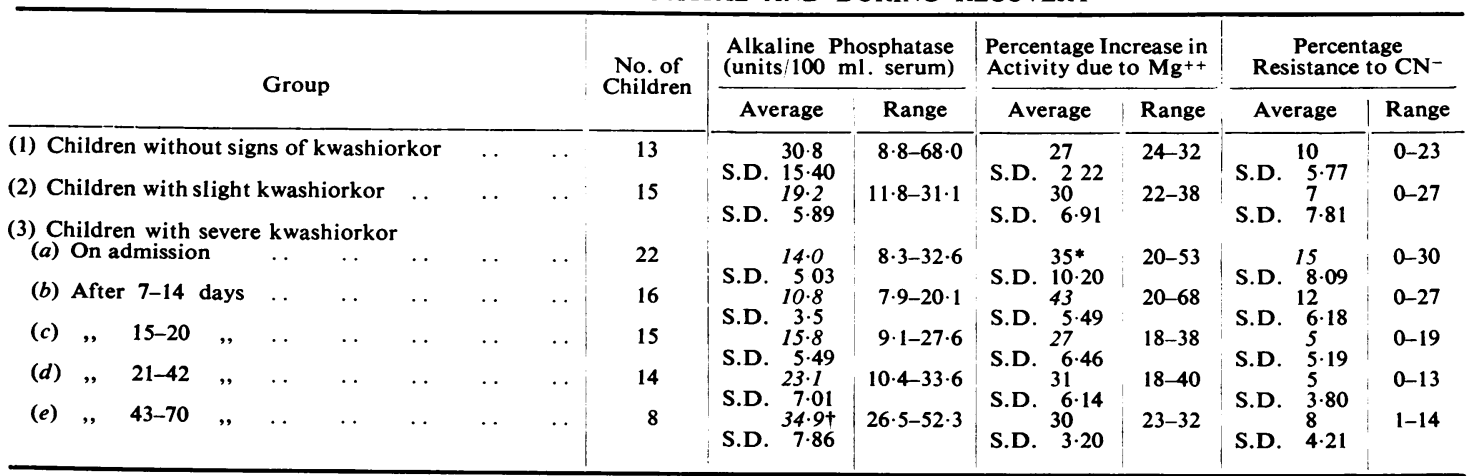

Each value printed in italics is significantly different, by statistical analysis, from that immediately above in the same column.

* Significantly different from value for Group 1 but not from that for Group 2.

$\uparrow$ Not significantly different from value for Group 1. 


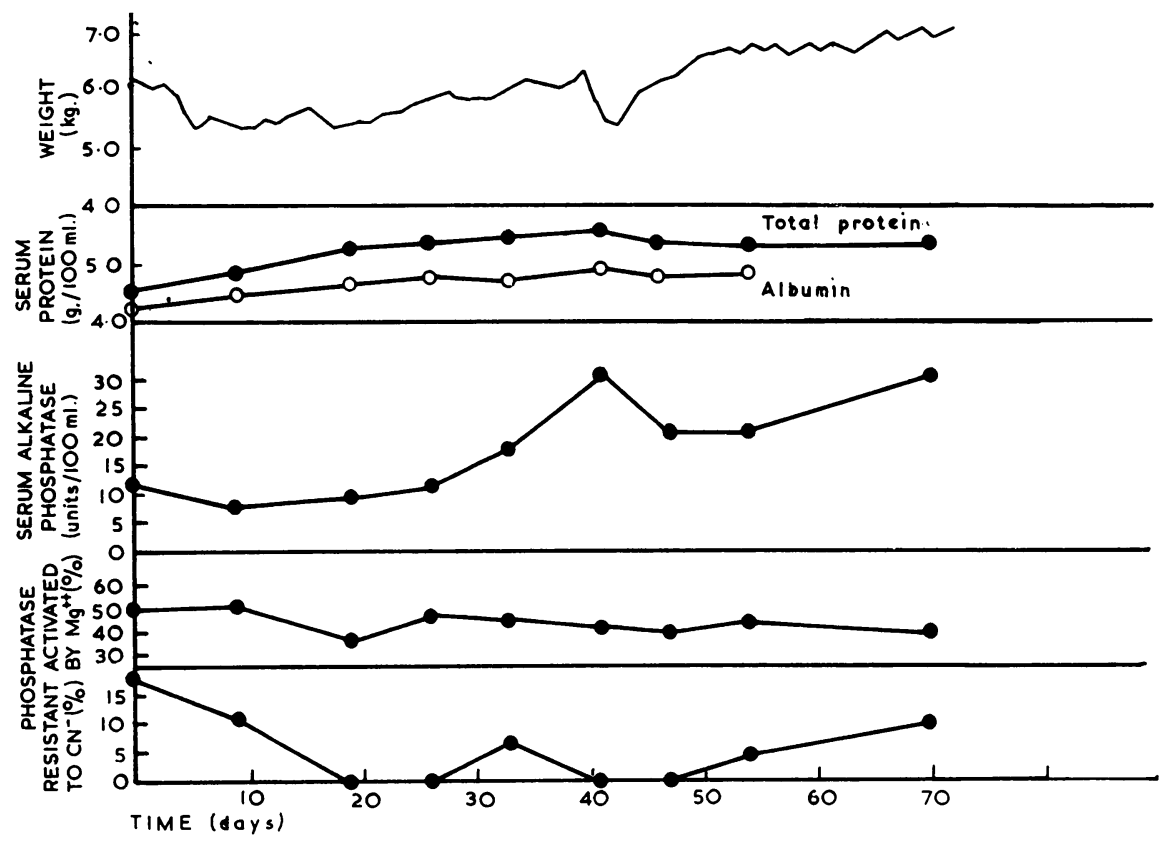

FIG. 1.-Francis. Boy aged 12 months. Severe kwashiorkor without complications. Grossly underweight; severe hair and skin changes; hair and skin changes; miserable but not anorexic. Clinical recovery was excellent despite a bout of diarrhoea, with slight dehydration, about the 40th day. The alkaline phosphatase activity, low at first, felland then rose. The response to $\mathrm{Mg}++$ was high on admission $(50 \%)$ and at nine days. It fell to a minimum value on the 19 th day, then settled to levels between 35 to $45 \%$, which were somewhat higher than was usually found during recovery. The percentage resistant to cyanide fell from the high initial level $(18 \%)$ to zero on the 19 th day, and was rising at the time of discharge.

reported by Stearns and Warweg (1933) for American children of the same age were between 8 and 15 Bodansky units, and by King (1953) for European children 11-28 King-Armstrong units. As the unit used in the present investigation is approximately three times the Bodansky unit, the average value of 30.8 units agrees with other normal values.

The average value for children with slight kwashiorkor was 19.2 units, a little more than half the figure for the children without kwashiorkor. The children with severe kwashiorkor had an average value of only 14.0 units. There was a further drop in this group to 10.8 units after seven to 14 days of treatment, which was followed by a steady rise to 34.9 units after 43 to 70 days of treatment. By that time in most cases the child was putting on weight well and the general condition was satisfactory. The phosphatase activity, having reached a value between 30 and 40 units, remained fairly constant. The final value was approximately the same as that for the children without signs of kwashiorkor.

Activation by Magnesium.-The percentage of enzyme activated by magnesium was virtually the same in the group without signs of kwashiorkor and the group with slight kwashiorkor, but the range was somewhat greater in the latter group. In the group with severe, untreated kwashiorkor the mean value was $35 \%$, which was significantly different from the value for the children withoub of signs of kwashiorkor, but not from that for the group with slight kwashiorkor. After seven to $1 \Phi$ days of treatment there was a rise to $43 \%$. It was followed by a drop to $27 \%$ in 15 to 20 days. The mean values after 21 to 42 and 43 to 70 days of treatment were $31 \%$ and $30 \%$. The small increase was without statistical significance.

Resistance to Inhibition by Cyanide.-There was no difference of statistical significance between the group without signs of kwashiorkor and the group with slight kwashiorkor in the resistance of the serum enzyme to inhibition by cyanide. In severe kwashiork or the percentage of enzyme resistant to inhibition was at first raised to 15 and after seven to 14 days of treatment was still 12. A drop to 5 was found after seven more days. In the last stages of treatment the figure was 8 . The slight rise, although without statistical significance, was probably not fortuitous, and it is discussed later.

The Range.-All the average values recorded in Table $I$ are statistically significant, but the varia- $\mathrm{N}$ tions about the average were considerable. This $\omega$ was especially marked in the group with severe kwashiorkor before and during treatment. It was found that, when the results obtained in individual cases were related to length of treatment, a change in the response to magnesium and cyanide that $T_{0}$ was more marked than was shown by the average $\stackrel{\vec{D}}{\mathbb{D}}$ values could often be recognized. Although there 


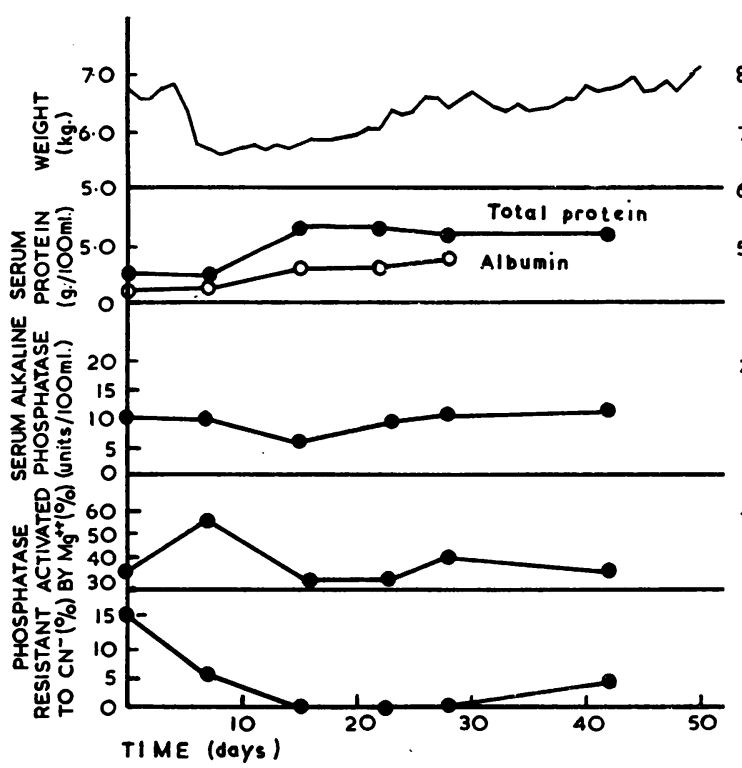

FIG. 2

had been careful selection of the severe cases, considerable variation in initial severity was unavoidable, and anorexia, the degree of psychological upset, or the presence of complicating infections could affect the course of recovery profoundly. Four individual cases, chosen to be illustrative, are presented in detail (Figs. 1 to 4 ). Three of them were severe cases of kwashiorkor and the fourth was a slight case that had been treated in the ward of the infantile malnutrition group. The body weight, the total serum protein and serum albumin, the alkaline phosphatase, and the percentages of enzyme activated by magnesium and remaining after cyanide inhibition, on admission and during the stay in hospital, are shown in the Figures.

\section{The Relation of Clinical Condition to Enzyme Changes During Treatment}

Changes in Basic Alkaline Phosphatase.-The four cases represented graphically in Figs. 1 to 4 are examples of different patterns of change in alkaline phosphatase activity in response to highprotein treatment. In the children severely ill (Figs. 1 and 2) the activity was low in the beginning and dropped in each case by about four units in the first stage of recovery. In the less severe case (Fig. 3) the alkaline phosphatase was low initially; it was at the same level six days later and had risen by over five units by the thirteenth day. If a drop did occur it must have been missed between the first and seventh day. Recovery, in this case, was unusually rapid. In

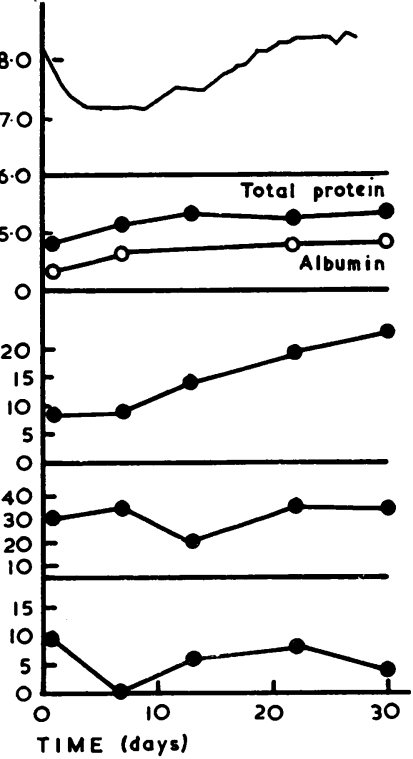

FIG. 3

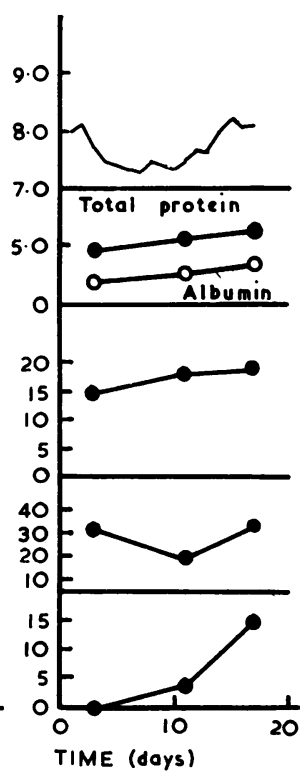

FIG. 4
FIG. 2.-Lukwago. Boy aged 16 months. Severe kwashiorkor with complicating pneumonia and bilateral hypopean ulcer. Grossly underweight; severe hair and skin changes; much oedema; very miserable; very anorexic. Clinical recovery was slow, but weight gain was fairly good after the infections had cleared up. The serum alkaline phosphatase showed a fall only on the 15th day, serum alkaline phosphatase showed a fall only on the 1sth day, then rose very slowly. The sensitivity to $\mathrm{Mg}^{++}$was highest on the seventh day, then fell. The percentage resistant to $\mathrm{CN}^{-}$fell from the initial high level $(16 \%)$ to zero on the 14 th day. It showed its first rise only on the 42 nd day of treatment.

FIG. 3.-Namagesere. Girl aged about 30 months. Moderately severe kwashiorkor; very underweight, but plump; severe hair and skin changes; much oedema; no misery; good appetite. fall after seven days in the activity of the basic alkaline phosphatase. It had risen sharply by the 13 th day and continued rising until the child was discharged on the 27 th day. The sensitivity to Mg++ fluctuated, but remained throughout in the range found in children without signs of kwashiorkor. Similarly, the percen children without signs of kwashiork. Similarly, the percentage resistant to $\mathrm{CN}^{-}$was never very high. It fell to zero on the seventh day, and then rose.

Fig. 4.-Sumani. Boy aged 20 months. Mild kwashiorkor; underweight, but plump; scanty hair; slight skin changes; oedema of legs; no misery; good appetite. Clinical recovery was good. The serum alkaline pho ++ fluctuated slightly about the value considered normal for children without kwashiorkor. The percentage resistant to $\mathrm{CN}^{-}$was lowest when the first sample was taken (on the third day) and rose during treatment. The value on discharge was a little higher than was usual in such cases.

the mild case (Fig. 4) the initial level was a little higher than in the other cases and there was an immediate steady rise from the beginning of treatment.

Further investigation has shown that the drop in activity during the early part of treatment occurs very seldom except in severe cases. As previously explained, the level of serum albumin on admission was used as an objective measure of severity, and it was found that in nearly every case in which 
the level was $1.8 \mathrm{~g} . / 100 \mathrm{ml}$. or less the fall in the phosphatase activity occurred: when the level was above $1.8 \mathrm{~g} . / 100 \mathrm{ml}$. a rise was more usual. In Kampala cases $1.8 \mathrm{~g}$. albumin is usually found in about $4.0 \mathrm{~g}$. total serum proteins, and this figure is equally valid as an index.

Sensitivity to Magnesium and Cyanide.-There was no direct correlation between the sensitivity to magnesium and the resistance to cyanide; especially during the first 14 days of treatment they often showed independent changes. The highest sensitivity to magnesium occurred almost entirely in the severest cases. In Group 3 (a) in Table I there were four instances of sensitivities of over $45 \%$, and in Group 3 (b) there were nine. In nearly every case in which the sensitivity to magnesium was elevated above $45 \%$, either on admission or after treatment had begun, the drop in phosphatase occurred.

On the other hand, no relationship could be found between the severity and resistance to cyanide inhibition. The general trend in severe and mild cases of kwashiorkor was for high values on admission, and for a decrease to a minimum value after two or three weeks of treatment. Four children in Group 3 (a) had low percentages (under 10) of enzyme resistant to cyanide on admission. Two of these children died after a few days, and the remaining two, one a very severe case and the other moderately severe (Fig. 3 ), both showed zero sensitivities after seven days of treatment.

Although it is not evident from Table I, almost all children passed through a period at which the sensitivity to magnesium and resistance to cyanide were at very low levels. It usually occurred after 14 to 20 days of treatment and sometimes continued for two or three weeks. A rise occurred when the basic enzyme level was approaching that finally reached.

\section{Discussion}

Few conditions are known in which the activity of serum alkaline phosphatase is markedly low. All occur in association with growth failure or depressed osteoblastic activity: low values have been reported in children with hypothyroidism (Albright, Sulkowitch, and Bloomberg, 1937 ; Talbot, Hoeffel, Shwachman, and Tuohy, 1941) and with scurvy (Shwachman and Gould, 1942). In other conditions in which the activity is abnormal, it is raised in association with pathological bone development or impairment of liver function. In acute kwashiorkor the lowered levels of serum alkaline phosphatase are probably related to the growth failure which is a constant feature.
In addition the liver is always involved: the amount of fat is usually increased, and the low albumin/globulin ratio and the high proportion of unbound cholesterol in the serum probably indicate impaired liver function.

The Indian workers who demonstrated increased concentrations of alkaline phosphatase in the liver tissue of children with acute kwashiorkor suggested that the accumulation was due to the inability of the liver to dispose of the excess enzyme in the normal way. It may be reasonable to expect the increased level in the tissue to be paralleled by a high level in the blood, but, as we have already shown, that does not occur. Some attempt at explanation seems to be called for. It may be assumed that in the severely ill child enzyme production in general is greatly reduced: the total amount of alkaline phosphatase which is produced is probably small, and the amount that collects in the liver may also be small, but the liver may be unable to deal satisfactorily even with that amount. As a result the enzyme accumulates in the liver, and the concentration in the serum is slightly raised. With treatment liver function is improved, the excess enzyme is removed from the liver, and there is a parallel fall in the serum leveP At the same time enzyme production, probably at several different sites in the body, increases, an 9 eventually the result of the opposing factors is a rise in the serum level. The rise will become apparent at different times, or the fall may not be seen at all, according to the extent of the influence of one factor or another.

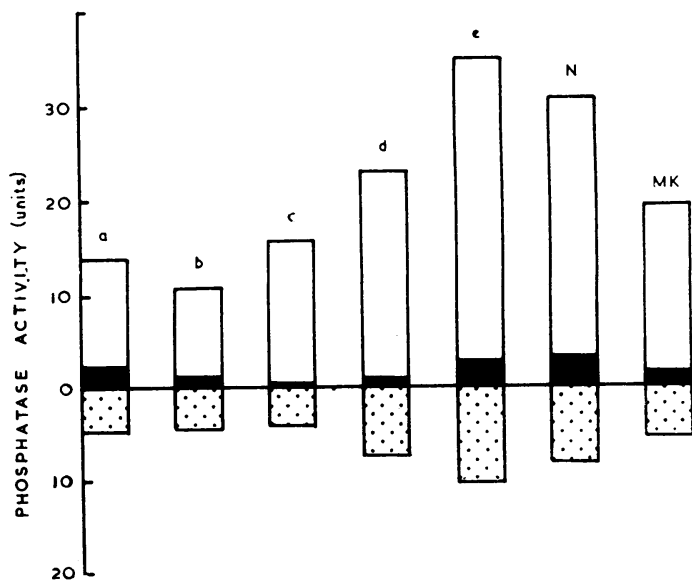

FIG. 5.-Phosphatase activity in units. Atove horizontalline shows basic activity, with residual activity after $\mathrm{CN}^{-}$(shaded portion). Below horizontal line shows enhanced activity due to $\mathrm{Mg}^{++}$. Columns a-e: severe kwashiorkor on admission and during treatment (as in Table I). Column N: children with no signs of $\mathbb{(}$ kwashiorkor. Column MK: children with mild kwashiorkor. 
There are obvious objections to this hypothesis, but the findings reported here on the changes in sensitivity to magnesium and cyanide during treatment give it some support. So far, the sensitivity to magnesium and resistance to cyanide have been related to the activity in the absence of added ions, on a percentage basis. The sensitivity to magnesium and resistance to cyanide have been represented in units of activity in Fig. 5. In the initial stages of recovery there are reductions in the activity that is not sensitive to magnesium, and in the activity that is resistant to cyanide. The former then increases, but the latter continues to decrease (until about the 20th day of treatment). Up to this time the activity sensitive to magnesium has remained virtually constant. After the 20th day the activity of all three kinds increases until a constant proportionality is reached resembling that found in children without signs of kwashiorkor.

It is difficult to explain this course of events without postulating the presence of at least three alkaline phosphatases in the serum, each with its own pattern of response to magnesium and cyanide. If this is so, they must be present in unusual proportions in the acute stage of kwashiorkor. An alternative theory, somewhat less attractive, is that in kwashiorkor the serum contains enzymes that normally do not appear in it, or substances that modify the response of phosphatase to added activators and inhibitors. There is plainly much more work to be done: it should include the investigation-difficult or impossible at Kampala-of children with hypothyroidism, with scurvy, and with various forms of growth failure. Useful information might also be gained from a study of rickets and other conditions in which the phosphatase level is high. The group of African children without signs of kwashiorkor all had infections, and children in the wards of the infantile malnutrition group have been observed when they contracted chickenpox, measles, and other common illnesses. In some of those children it was found that the level of basic alkaline phosphatase appeared to be depressed, to the extent of a few units, as a result of the infection, but in none of them was the pattern of response to magnesium and cyanide abnormal. In the children who were considered to have slight kwashiorkor the basic phosphatase activity was considerably lower than it was in the children with none of the signs, but there were no obvious differences in the sensitivity to magnesium and cyanide in the two groups. Slight kwashiorkor differed from severe kwashiorkor, however, in that the severe condition not only showed an even lower level of basic phosphatase activity but also increased in sensitivity to magnesium and resistance to cyanide. The extent to which these changes are peculiar to severe kwashiorkor must await further investigation.

At the moment there is little exact information regarding the source of serum alkaline phosphatase in man. It is generally supposed that bone makes a large contribution to the level of enzyme, and the great increase found towards the end of treatment of the cases described here may reflect a resumption of bony development. This possibility is being investigated with the help of serial radiographs of the bones, and the results will be reported at a later stage. It is obvious, however, that bony development is only a part of growth, and other developing tissues may make considerable contributions to the high levels of the serum enzyme found in children who are rapidly growing.

\section{Summary}

The alkaline phosphatase and its response to $\mathrm{Mg}^{++}$as activator and $\mathrm{CN}^{-}$as inhibitor were measured in the serum of African children who had (1) no signs of kwashiorkor, (2) slight kwashiorkor, and (3) severe kwashiorkor, before and during treatment with milk protein.

The enzyme level was considerably lower in the children with slight kwashiorkor than in the children without signs of the disease.

In the majority of cases of severe kwashiorkor:

(a) The enzyme level was even lower than in slight kwashiorkor, fell after seven to 14 days of treatment and afterwards rose steadily towards the level usually considered normal. The fall occurred most consistently in the cases in which the serum albumin was $1.8 \mathrm{~g}$. $/ 100 \mathrm{mi}$. or less.

(b) The percentage activated by $\mathrm{Mg}^{++}$was high at first, increased after seven to 14 days of treatment and afterwards fell.

(c) The percentage resistant to $\mathrm{CN}^{-}$was high at first, and decreased during treatment, reaching a minimum after 15 to 20 days.

(d) After prolonged treatment (40-70 days) the percentages activated by $\mathrm{Mg}^{++}$and resistant to $\mathrm{CN}^{-}$reached values similar to those found in the children without signs of kwashiorkor.

The causes of the fall in enzyme level are discussed. The fall, and the other changes found during treatment, suggest that the serum may contain a series of alkaline phosphatases.

The clinical grading of the cases investigated was made by Dr. R. F. A. Dean, and I am grateful to him for his help in the presentation of the results. 


\section{REFERENCES}

Albright, F., Sulkowitch, H. W., and Bloomberg, E. (1937). Amer. J. med. Sci., 193, 800.

Allen, R. J. L. (1940). Biochem. J., 34, 858

Behar, M. (personal communication). I.N.C.A.P., Guatemala City, Guatemala, Central America.

Behrendt, H. (1949). Diagnostic Tests for Infants and Children. Interscience Publishers, New York.

Bersohn, I. (personal communication). South African Institute for Medical Research, Johannesburg, South Africa.

Bodansky, A., and Jaffe, H. L. (1933-34). Proc. Soc. exp. Biol. $(N . Y, 1,31,107,1179$

Dean, R. F. A. (1952). Brit. med. J., 2, 791. (1954). J. trop. Med. Hyg., 57, 283.

- and Schwartz, R. (1953). Brit. J. Nutr., 7, 131

Ely, J. O., and Ross, M. H. (1951). Nature (Lond.), 168, 323

Gomori, G. (1946). Proc. Soc. exp. Biol. (N.Y.), 62, 33.

Hansen, J. D. L. (personal communication). Department of Paediatrics, Groote Schuur Hospital, Observatory, Capetown, South Africa.
Jayasekera, H. T. W., Mel, B. V. de, and Cullumbine, H. (1951 Ceylon J. med. Sci., 8, 1.

King, E. J. (1953). Brit. med. Bull., 9, $1 \in 0$

Miller, L. L. (1950). J. biol. Chem. 186, 253.

Ramalingaswami, V., Sriramachari, S., and Patwardhan, V. N. (1954). Indian J. med. Sci., 8, 433.

Roche, J., and Sarles, H. (1950). Biochim. biophys. Acta, 5, 275.

(1951). Bull. soc. Chim. biol. (Paris), 33, 667.

Rosenthal, O., Fahl, J. C., and Vars, H. M. (1952). J. biol. Chem., $\frac{\bar{\sigma}}{\mathrm{S}}$

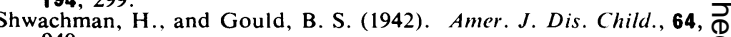
949.

Sriramachari, S., and Ramalingaswami, V. (1953). Indian J. Pediat. 20, 1 .

Stearns, G., and Warweg, E. (1933). J. biol. Chem., 102, 749.

Talbot, N. B., Hoeffel, G., Shwachman, H., and Tuohy, E. L. $\vec{\bigcirc}$ (1941). Amer. J. Dis. Child., 62, 273.

Trowell, H. C., Davies, J. N. P., and Dean, R. F. A. (1954). Kwashior- 二 kor. Arnold, London.

Waterlow, J. C. (1948). Spec. Rep. Ser. med. Res. Coun. (Lond.), No. 263. 